9. Владимиров В.М. Вступ до спеціальності „Журналістика»: навч. посібник. К.: МАУП, 2006. с. 217.

10. Алексей Батурин, 2019. Катализаторы бунта. 6 фраз, с которых начинались революции в разных странах. Фокус: веб-сайт. URL: https://focus.ua/world/361090/ (дата звернення: 21.02.2021).

11. Bloomberg: США осуществляют цензуру интернета под предлогом борьбы с ненавистью. Царьград: веб-сайт. https://tsargrad.tv/ news/bloomberg-ssha-osushhestvljajut-cenzuru-interneta-pod-predlogomborby-s-nenavistju_120296 (дата звернення: 21.02.2021).

12. Юваль Ной Харар, 2018. Большинство людей не осознают, что происходит: речь израильского историка в Давосе. Букви: веб-сайт. URL: https://bykvu.com/ua/bukvy/84181-bolshinstvo-lyudej-ne-osoznayutchto-proiskhodit-rech-izrailskogo-istorika-v-davose/ (дата звернення: 21.02.2021).

13. Ученые создали алгоритм, который сможет определять эмоции толпы через видеоролики. Iнфоратор: веб-сайт. URL: https://life.informator.press/uchen-e-sozdaly-alhorytm-kotor-y-smozhetopredeliat-motsyy-tolp-cherez-vydeorolyky/ (дата звернення: 21.02.2021).

\title{
DOI https://doi.org/10.30525/978-9934-26-042-1-8
}

\section{ІНСТРУМЕНТИ СОЦАЛЬНИХ МЕРЕЖ ДЛЯ РЕАЛІЗАЦІЇ ГРОМАДСЬКИХ ІНІЦІАТИВ}

\author{
Ляшук Н. В. \\ дочент кафедри інформачійної діяльності та туризму \\ Відкритий міжнародний університет розвитку людини «Украӥна» \\ м. Луиьк, Україна
}

В умовах сучасного розвитку інтернет-технологій, створення мережевих структур (е-соцмереж), соціальних медіа, стали розглядатись багатьма дослідниками як додатковий інструмент сприяння становленню й розвитку громадянського суспільства та самоорганізації громадян. Адже, як зазначає С. Даниленко: «комунікаційний простір мережі Інтернет, 3 позицій теорії та практики відкритого демократичного суспільства, $є$ невід’ємною частиною громадської сфери, відкритою для всіх членів суспільства, як для публічних дебатів, так і для обміну думками між громадянськими організаціями, активними індивідуумами, групами й спільнотами» $[1$, с. 3$]$. 
Соціальні мережі перестали бути лише середовищем комунікації і перетворилися на засіб самоорганізації суспільства, громадянської активності, досягнення цілей. Їхнє використання цілком виправдане, враховуючи сучасні технічні можливості соціальних мереж - це швидкість поширення інформації, інтерактивність (зворотній зв'язок), значне охоплення аудиторії тощо.

Дослідники стверджують, що характерним явищем останніх років стало помітне переміщення активності наших співвітчизників, особливо в Центрі та на Заході України, із мереж, створених у Росії, до провідних транснаціональних мереж, зареєстрованих у США Facebook, Blogger, Twitter. При цьому особливої популярності все більше набуває Facebook, що в цілому стало дуже характерним для держав Східно-Центральної Свропи, які обрали демократичний вектор розвитку: Польщі, Угорщини, Болгарії, Румунії, Словаччини, Литви, Латвії, Молдови, Грузії. Присутність у Facebook численних представників наукової, освітянської, творчої інтелігенції, включаючи широковідомих діячів, чималою мірою визначає серйозність проблематики спілкування, у якій помітне місце займає обмін важливими новинами культури, науки, суспільного життя, влучними оцінками й оригінальними судженнями 3 багатьох актуальних гуманітарних проблем. Facebook все більше позиціонується в Україні як середовище спілкування інтелігенції [3, с. 15].

На прикладі мережі Facebook можна виокремити наступні форми привернення уваги та залучення громадськості до ініціатив чи вирішення проблем:

- Facebook-cторінки, групи. Зокрема громадські організації різних сфер діяльності активно ведуть сторінки в соцмережах, до яких долучаються громадяни.

- Пости лідерів громадської думки, лідерів громадських організацій чи ініціатив. Найпопулярніші українські блогери, лідери громадських організацій перетворюються на впливових лідерів думок, сприяють процесам самоорганізації громадян.

- Facebook-nodiï. Передбачають анонси проведення різного роду громадських акцій - благодійних, волонтерських, мистецьких, екологічних, студентських, політичних, патріотичних.

- Онлайн-флешмоби. За допомогою хештега пости користувачів соціальної мережі об'єднуються за певною темою (наприклад, \#Свромайдан, \#АТО, \#Порошенко, \#FreeSavchenko, \#JesuisVolnovakha тощо), що дозволяє відслідковувати резонанс, емоційне забарвлення й позиції громадян щодо тієї чи іншої політичної події, персони або явища.

Як слушно зазначає Л. Чуприна: «сьогодні, соціальні мережі $€$ унікальною платформою для консолідації різних груп суб'єктів на 40 
основі спільності їх інтересів, при цьому в результаті комунікативної взаємодії виникає масштабний синергетичний ефект. Соціальні мережі сприяють структуризації комунікативного простору, створенню віртуальних співтовариств, які часто на практиці перетворюються на громадські об'єднання. А громадським інституціям дають можливість поширювати свої ідеї, залучати до своїх лав нових членів та координувати їх дії. Спостерігається взаємопроникнення повсякденної соціальної реальності й віртуальної» [4].

Соціальні мережі займають важливе місце серед електронних інструментів, які використовують у своїй діяльності організації громадського суспільства. Згідно 3 результатами опитування, яке проводилося громадською організацією «Лабораторія досліджень ТЦК», 81\% ОГС використовують у своїй діяльності соціальні мережі. При цьому в тих організаціях, які користуються соціальними мережами, Facebook $\epsilon$ найбільш популярним $(99 \%$ організацій використовує цю мережу) [2, с. 23]. Через соцмережі громадські організації поширюють інформацію про свою діяльність, досягнення, фінансові звіти, а також заохочують друзів і колег підтримати організацію через внески, підпис петиції тощо.

Основними перевагами використання соціальних мереж для громадських ініціатив постають:

безпосередня взаємодія 3 аудиторіями за допомогою комунікаційних технологій зв'язків 3 громадськістю;

$>$ швидкість поширення своєчасної інформації;

$>$ платформа для публічного обговорення, вирішення важливих проблем, пропагування ідей;

залучення потрібної аудиторії, сегментів населення, яких важко досягти за допомогою традиційних засобів масової інформації;

$>$ швидка організація публічних подій: мітингів, протестів, флешмобів.

Великі потенційні можливості соціальних мереж у вираженні суспільних настроїв, втіленні в життя ідей громадянської солідарності яскраво виявилися у нинішній час випробувань, які переживає Україна. Мережі стали не лише платформою для обговорень гострих проблем сьогодення, а й важливим рушієм громадянської активності, засобом мобілізації зусиль громадян на реалізацію конкретних гуманітарних проектів волонтерської допомоги Збройним силам України, постраждалим на Сході України, координації дій громадянського суспільства.

Помічено, що соціальні мережі часто сприяють створенню віртуальних співтовариств, угрупувань, які в реальному житті формуються в організації громадського суспільства. 
За допомогою соціальних мереж створюють успішні проєкти, спрямовані також на вирішення локальних проблем, які не передбачають формального членства. Наприклад, проект «УкрЯма» (https://www.facebook. com/ukryama/), ініціатива «Зробимо Украӥну чистою» (https://www.facebook.com /LetsDoItUkraine/) - всеукраїнська екологічна громадська організація. Залучає людей до дій з покращення довкілля, шляхом спільної організації масштабних екологічних акції.

Соціальні мережі помітно впливають на взаємодію державної влади і суспільства. Зокрема, використання соціальних мереж дає можливість оперативно виносити громадянські ініціативи на публічне обговорення до інститутів влади, що у свою чергу сприяє формуванню культури взаємодії, партнерства влади та громадськості.

Отже, соціальні інтернет-мережі стають потужною платформою для організаційної комунікації, реалізації громадянських ініціатив, волонтерських проєктів, що сприяють, зміцненню суспільної солідарності, нарощуванню громадянської активності, довіри як необхідних умов для розвитку демократичного суспільства.

\section{Література:}

1. Даниленко С. I. Громадянський вимір інформаційнокомунікаційної революції: концептуально-теоретичні та політикоприкладні аспекти: автореф. дис. ... д-ра політ. наук : 23.00.03 / нац. унт ім. Т. Шевченка. Київ. 2018. 36 с.

2. Звіт за результатами дослідження ОГС м. Києва / упоряд. Любов Паливода. Київ. : BAITE, 2017. 40 c. URL: http://dsk.kievcity.gov.ua/ files/2017/11/27/report_kyivcso.pdf (дата звернення : 18.12.2020).

3. Соціальні мережі як інструмент взаємовпливу влади та громадянського суспільства. Наукова доповідь за темою дослідження / О. С. Онищенко, В. М. Горовий, В. І. Попик та ін.; НАН України, Нац. б-ка України ім. B.I. Вернадського. Київ, 2014. URL: http://nbuviap.gov.ua/images/dopovidi__ konf/smivvts.pdf (дата звернення : 29.11.2020).

4. Чуприна Л. Соціальні мережі як інструмент реалізації громадських ініціатив. Центр досліджень соціальних комунікацій НБУВ. http://nbuviap.gov.ua/index.php?option=com_content\&view= article\&id=1085:sotsialni-merezhi-yak-instrumentrealizatsijigromadskikhinitsiativ (дата звернення : 05.12.2020). 